tical importance. Mr. Henderson found that under suitable conditions an a-particle may cause the detonation of nitrogen iodide, about one a-particle in $10^{7}$ or $10^{8}$ being effective. He suggests that other unstable substances may be similarly affected. The question naturally arises as to whether any of the explosives commonly used are sufficiently unstable to be detonated in this way. As they are all very much more stable than nitrogen iodide we would expect that the chance of an a-particle causing detonation would be much smaller, so that an explosion might only occur after a lengthy exposure to a copious source of a-particles. Still, in view of the almost universal presence of small traces of radioactive matter, it is possible that some unexplained explosions have been brought about in this way. It would appear to be worth while to conduct an investigation into the possible effect of $a$-particles on various explosives and detonators. If it is found that there is even the remotest possibility of detonation occurring, precautions should be taken in the manufacture of explosives to reduce the radioactive contamination to the lowest possible value.

Horace H. Poole.

Royal Dublin Society, July I I, r922.

\section{Occurrence of a Grystalline Style in the American Slipper Limpet (Crepidula fornicata) and its Allies.}

DURING-recent investigations, carried out with the aid of a Government grant, on the oyster beds in the river Blackwater, freshly caught specimens of the American slipper-limpet (Crepidula fornicata) were examined fresh microscopically, and the interesting fact was established that this species possesses a crystalline style. Individuals which have been out of water 24 hours or "more still possess remains of the style, which has undergone partial solution. Crepidula differs therefore in this respect from the native oyster (O.edulis), the styleof which is frequently completely dissolved within 3 to 5 hours after individuals are taken out of water, and is completely dissolved in all specimens after about ro hours out of water.

In the style of Crepidula occasional Spirochætes (Cristispira balbiani?) were seen, but not identified. By analogy it was suggested that the allies of Crepidula should also possess a crystalline style, and an examination of fresh specimens at Plymouth at once proved the surmise correct in the case of the species Calyptrea chinensis and Capulus hungaricus. It is highly probable, therefore, that a crystalline style is present in the whole of the Calyptræidæe and the Capulidæ; it is also not improbable that a style may be present in all sedentary non-parasitic Streptoneura.

I have long suspected that a crystalline styleparticularly in molluscs-is associated with a mode of feeding which consists essentially in the capture of planktonic organisms by mucus controlled by harmonised ciliary mechanisms. The discovery of a crystalline style in Crepidula and some of its allies, which all feed in the manner mentioned, lends some support to this idea; but too little is known of the habits of other gastropods which definitely possess a style, to permit of a general correlation of the presence of style with capture of food by means of mucus. Some indications have been obtained by rough hurried experiments that the style substance is a good solvent for mucus; and if this observation can be confirmed it may well be shown that the dissolving of the mucus enveloping food-masses is one of the most important functions of the crystalline style.

The Marine Biological Laboratory, J. H. ORTON. Plymouth, July I3.

\section{Sense of Smell in Birds.}

IN the issue of NATURE for June I 7 there is a discussion on the inadequacy of present observations on the sense of smell in birds. Perhaps the following notes would be of interest. They are from an account of the habits of the birds of Trinidad which will be published shortly by the Department of Agriculture of that island.

On September 20, I9I8, I observed large numbers of the black vulture (Cathartes fotens) collected on and round a field which had recently been experimentally manured with liquid slaughter-house refuse and could be smelt a quarter of a mile away, although nothing was visible to the eye. A few red headed vultures (Cathartes aura) were also present. In Panama the same birds quickly found the body of an animal that I put close to the trunk of a thick tree, quite invisible from above.

Still more interesting is an observation by Hart (Bull. Dept. Agr. Trinidad II., p. I55), who records that Cathartes foetens used to collect in the morning hours on trees near a plant of Aristolochia gigas v. sturtevanti which was flowering, and which has a particularly strong odour. There can be no doubt that these birds have an efficient sense of smell. At the same time I think that their congregation in numbers is due to watching the movements of their neighbours.

Ministry of Agriculture, Cairo, Egypt, June 29 .

\section{The Skull of Sir Thomas Browne.}

IT may be known to some readers of NATURE that the skull of Sir Thomas Browne has recently been reinterred at Norwich, but that previously it came to London, where careful measurements, drawings, and tracings of it were made. It is proposed to publish a full account of the skull in Biometrika, but it would add much to the interest of the proposed monograph if it were accompanied by a series of reproductions of the portraits and engravings of one of the most noteworthy of Englishmen who have combined the study of medicine with the pursuit of literature.

The large number of plates required to illustrate adequately the relation of the skull to the portraits renders - under the present conditions of both printing and illustrative work - the appearance of a complete monograph, such as we desire to see issued, very difficult. We propose, therefore, to issue one hundred copies of the monograph at the price of one guinea each, if lovers of Sir Thomas Browne can be found in adequate numbers to subscribe for copies. Will you kindly permit us to appeal through your columns for the names of those who are willing to aid in this scheme for putting on permanent record the physical aspect of the author of the " Religio medici," who, by that and his other works, has won a unique position in the heart as well as in the mind of every cultured Englishman ? Willingness to subscribe may be notified to either of the undersigned at the Royal College of Surgeons, Lincoln-Inn Fields, and University College, London, respectively.

ARTHUR KeITH.

London, July ז2. 